\title{
GROWTH AND DEVELOPMENT OF WETLAND-GROWN TARO UNDER DIFFERENT PLANT POPULATIONS AND SEEDBED TYPES IN UGANDA
}

\author{
R. TUMUHIMBISE, H. L. TALWANA, D.S.O. OSIRU, A.K. SEREM ${ }^{1}$, B.K. NDABIKUNZE², J.O.M. \\ $\mathrm{NANDI}^{3}$ and V. PALAPALA ${ }^{4}$ \\ Department of Crop Science Makerere University, P. O. Box 7062 Kampala, Uganda \\ ${ }^{1}$ Department of Agricultural Resources Econonomics and Marketing, Moi University, \\ P. O. Box 1125-30100, Eldoret, Kenya \\ ${ }^{2}$ Department of Food Science and Technology Sokoine University of Agriculture, \\ P.O.Box 3006, Morogoro, Tanzania \\ ${ }^{3}$ Department of Social Sciences, Masinde Muliro University of Science and Technology, \\ P. O. Box190-50100 Kakamega, Kenya \\ ${ }^{4}$ Department of Biological Sciences, Masinde Muliro University of Science and Technology, \\ P. O. Box190-50100 Kakamega, Kenya
}

(Received 4 January, 2009; accepted 22 July, 2009)

\begin{abstract}
Taro [Colocasia esculenta (L.) Schott] is a member of the Araceace family that is a staple food for many people in developing countries in Africa, Asia and the Pacific Islands. It is widely grown in Uganda but the extent of its production and consumption is not known, partly because it has been ignored as legitimate crop for research and development (R\&D), and it is managed outside the conventional agricultural production, marketing and economic channels. Therefore, there is limited information on many aspects of taro, including agronomic practices. In order obtain data that can support improved and sustainable taro production, a field trial was conducted over two cropping seasons at Kabanyolo in central Uganda, to determine the effect of three taro plant populations $(10,000$, 17,760 and 40,000 pph) and two seedbed types (flat and ridged seedbed) on growth and yield of taro. The treatments were arranged in a split - split - plots design, with three replications. Seedbed type was in the main plot and plant populations in the sub-plots. These were further split to accommodate five sampling dates for plant growth. Each experimental subplot measured $6 \mathrm{~m} \mathrm{x} 6 \mathrm{~m}$ and contained 36, 64 and 144 experimental plants, respectively. During a 5-month growth period, leaf area index (LAI) and corm yield were significantly $(\mathrm{P}<0.05)$ higher in closely spaced plants (high plant population). Seedbed type had no $(\mathrm{P}>0.05)$ effect on taro growth and yield. However, using high plant population may not be recommended because of the enormous amount of planting material that would be needed. From this study, a moderately wide spacing of $0.75 \mathrm{~m}$ x $0.75 \mathrm{~m}$ which produced an acceptable yield of $5.5-6.8 \mathrm{t} \mathrm{ha}^{-1}$ would be recommended.
\end{abstract}

Key Words: Agronomy, Colocasia esculenta, corm, LAI

\section{RÉSUMÉ}

Le Taro [Colocasia esculenta (L.) Schott] est membre de la famille Araceace qui est un aliment de base pour un grand nombre de personnes dans les pays en développement en Afrique, Asie et Pacifique. Le Taro est largement cultivé dans bon nombre de zones humides en Ouganda, mais comme une activité de production informel gérée sans appui de la recherche et la vulgarisation agricole. Par conséquent, il y a peu de renseignements sur de nombreux aspects de Taro, y compris les pratiques agronomiques. Afin d'obtenir des données qui peuvent soutenir une production durable et améliorée de Taro, un essai au champ avait été établi au centre de l'Ouganda en deux saisons culturales afin de déterminer l'effet des trois populations de plantes de Taro $(10.000 ; 17.760$ et 40.000 plants par hectare (pph) et deux types de bandes de plantation (plate et rugueuse) sur la croissance et le 
rendement de Taro. Les traitements avaient été organisées en split - split - plot dans un modèle en blocs completement randomisés avec trois réplications. La bande de sémis type était dans la parcelle principale qui avait été divisée pour recevoir trois populations végétales et celles-ci étaient en plus divisées pour recevoir cinq dates de plantation échantillonnées pour la croissance des plantes. Pendant une période de croissance de 5 mois, l'index de surface de feuilles (LAI) et le rendement en bulbe étaient significativement plus élevés $(\mathrm{P}<0,05)$ dans les plantes étroitement espacées (plante à population dense), tandis que le type de bande de plantation n'avait pas affecté la croissance et rendement de Taro. Toutefois, une densité de plantation élevée pourrait ne pas être recommandée en raison de la quantité énorme de materiel de plantation qui serait nécessaire en plus de rendement net réduite par unité de matériel de plantation. De cette étude, un espacement modérément large de 0,75 m x 0,75 m qui avait produit un rendement acceptable de 5,5-6,8 tonnes par hectare pourrait être recommandé. Le choix du type de bande de plantation à être utilisée pour la production de Taro doit dépendre de la topographie et du degré de l’humidité de la zone de production.

Mots Clés: Agronomie, Colocasia esculenta, bulbe, LAI

\section{INTRODUCTION}

Taro [Colocasia esculenta (L.) Schott] is a member of the Araceace family that is a staple food for many people in developing countries in Africa, Asia and the Pacific (Agueguia et al., 1992). It is produced mainly in Africa (especially in Nigeria) and Asia (mainly China), but it is most important per capita in Oceania (Howeler et al., 1993; Onwueme, 1999). The cultivated species of Taro may be distinguished into two main groups; the "eddoes" and the "dasheen" types (Ki-zerbo, 1990; Onwueme, 1994; Valerio, 1988; IPGRI, 1999). The eddoes types have side tubers (cormels) that may be $5-20$ in number and become as big as the mother corm. The cormels are usually absent in the dasheen types and it is the mother corm which is the main storage organ (IPGRI, 1999).

The corm and cormel which are the major economic parts have a nutritional value comparable to potato (Wang, 1983), while the young leaves and petioles which are occasionally used for food contains about $23 \%$ protein on a dry weight basis. It is also a rich source of calcium, phosphorus, iron, Vitamin C, thiamine, riboflavin and niacin, which are important constituents of human diet (Onwueme, 1999; Ndon et al., 2003).

Where grown in Uganda, Taro corms have a high economic value in urban markets. Its production provides employment to many people; and the crop maintains ground cover in the fields (Talwana et al., 2009). However, there is very limited local research on Taro in Uganda and its actual contribution to food security and economy is underestimated. Also, its profile on the national research and conservation agenda is miserably low. It is not surprising, therefore, that the average Taro yields in Uganda remains very low $(\leq 1 \mathrm{t}$ $\mathrm{ha}^{-1}$ ) for the majority of smallholder producers annually (Talwana et al., 2009), compared to the African and world average of 5.9 and $6.6 \mathrm{t} \mathrm{ha}^{-1}$, respectively (FAO, 2008).

It is possible that the status of Taro in Uganda can be improved to levels held by potato (Solanum tuberosum), sweet potato (Ipomoea batatas) and cassava (Manihot esculenta). This will require development of technologies that improve Taro yields to levels that are nearer its potential. There is, for example, urgent need to understand how various abiotic, biotic, and crop management factors impact on Taro growth and development in Uganda.

The objective of this study was, therefore, to determine the influence of plant populations and seedbed types on Taro growth and yield in an effort to develop a package of agronomic practices for improved production of Taro in Ugandan conditions.

\section{MATERIALS AND METHODS}

A field experiment was conducted at the Makerere University Agricultural Research Institute Kabanyolo (MUARIK), located about 14 km North East of Kampala, 1250 -1320 metres above the sea level. The soils at MUARIK are deep, highly weathered with a $\mathrm{pH}$ of $5.0-6.0$. The climate is tropical, with annual rainfall of about $1300 \mathrm{~mm}$, divided into two peaks, March to May and October to November. The daily maximum temperatures vary from $26^{\circ} \mathrm{C}$ in July to $28.5^{\circ} \mathrm{C}$ in 
January; daily minimum temperatures vary from $15.5^{\circ} \mathrm{C}$ in July/August to $17.4^{0} \mathrm{C}$ in April.

Taro basal stems (the apical $1-2 \mathrm{~cm}$ of the corm with the basal $15-20 \mathrm{~cm}$ of the petioles attached) collected from neighbouring farmers' fields were planted out in the field in August 2007 and March 2008 and arranged in a split - split - plot design with three replications. Each replication contained two main plots (seedbed types) which were split to accommodate three plant spacing: $1 \mathrm{~m} \mathrm{x} 1 \mathrm{~m}$ $\left(10,000\right.$ plants ha $\left.^{-1}, \mathrm{ph}\right), 0.75 \mathrm{~m} \times 0.75 \mathrm{~m}(17,760$ ph) and $0.5 \mathrm{~m} \mathrm{x} 0.5 \mathrm{~m}(40,000 \mathrm{ph})$. These were further split to accommodate five sampling dates for plant growth. Each subplot measured $6 \mathrm{~m} \times 6$ $\mathrm{m}$ and contained a total of 36, 64 and 144 Taro plants, for the plant spacing $1 \mathrm{~m} \mathrm{x} 1 \mathrm{~m}, 0.75 \mathrm{~m} \mathrm{x}$ $0.75 \mathrm{~m}$ and $0.5 \mathrm{~m} \times 0.5 \mathrm{~m}$, respectively. The experiment was set up in a swampy area, which was filled using hand hoes.

Plant growth was evaluated at 30, 60, 90, 120 and 150 days after planting (DAP). At each evaluation, plant height $(\mathrm{cm})$ was measured from the ground level to the shoot apex. Also, the standing leaves on each individual plant were counted; and leaf area index was estimated from linear measurements of leaf blades (Goenaga and Singh, 1996). Additionally, data were collected on below ground plant growth parameters, namely, corm length, corm diameter, and fresh corm weight.

Corm length was the distance from the tip of the corm to a point where the outer leaf petiole attached to the corm. The diameter of the cross section of the corm at the point where the outer leaf petiole attached to the corm was taken as the corm diameter. Fresh corm weight of harvested plants from $3 \mathrm{~m} \times 3 \mathrm{~m}$ subplots marked out of the original $6 \mathrm{~m} \times 6 \mathrm{~m}$ plots were obtained to estimate yield per hectare.

Data collected were subjected to analysis of variance using Generalised Linear Model (GLM) procedures of GenStat ${ }^{\circledR}\left(10^{\text {th }}\right.$ Edition) Computer programme and the means were separated using least significance difference (LSD) at 5\% probability level.

\section{RESULTS AND DISCUSSION}

Figures 1 - 4 show Taro plant growth at three different plant populations on two seed bed types through a 5 month growing period. The first 90 DAP were characterised by increase in plant height (Fig. 1), number of leaves (Fig. 2), length of the leaf petiole (Fig. 3) and leaf area index (Fig. 4). Plant height before 90 DAP (30 and 60 DAP) was significantly $(\mathrm{P}<0.05)$ lower than after 90 DAP (90, 120 and 150 DAP). Leaf petiole length increased with DAP; characterised by a sharp increase between 30 and 90 DAP, after which it nearly leveled out ( $90-150$ DAP). Leaf area index was significantly $(\mathrm{P}<0.05)$ highest in the closely spaced plants and lowest in the widely spaced plants although the number of leaves did not change appreciably throughout the 150 days of Taro growth (Fig. 4).

Corm growth was characterised by a slow growth period during the first 30 DAP followed by a period of growth in which corm diameter (Fig. 5) and length (Fig. 6) increased rapidly throughout the 150 days assessed. Both corm diameter and length were not significantly $(\mathrm{P}>$ 0.05 ) influenced by seedbed preparation and plant population. However, they were consistently lower in the closely spaced plants than the widely spaced plants. Similarly, corm fresh weight increased with DAP, being highest at $150 \mathrm{DAP}$ (Fig. 7). Taro yields were significantly $(\mathrm{P}<0.01)$ higher for plants spaced at $0.5 \mathrm{~m} \times 0.5$ $\mathrm{m}$, followed by $0.75 \mathrm{~m} \times 0.75 \mathrm{~m}$ and lower for plants spaced at $1 \mathrm{~m} \times 1 \mathrm{~m}$. Seedbed types did not significantly $(\mathrm{P}>0.05)$ affect corm yield.

The observed Taro growth and yield patterns are similar to those reported for aroids elsewhere (Goenaga and Chardon, 1995; Goenaga, 1996), although with lower values, probably because the study here did not use additional water supply or other production inputs. Plant populations have been reported to influence Taro growth; high plant populations being associated with higher LAI and corm yields due to high number of shoots per unit area (Ezumah and Plucknett, 1981; Prasad and Singh, 1992) and high number of corms per unit area (Onwueme, 1994), respectively.

The maximum LAI of 4.3 observed in closely spaced plants at 90 DAP was within the range for the theoretical optimum LAI of 4-5 (Scholberg et al., 2000). Similarly, the highest yield of $8.4-$ $10.8 \mathrm{tha}^{-1}$ observed in closely spaced plants at 150 DAP was higher than the African and world 

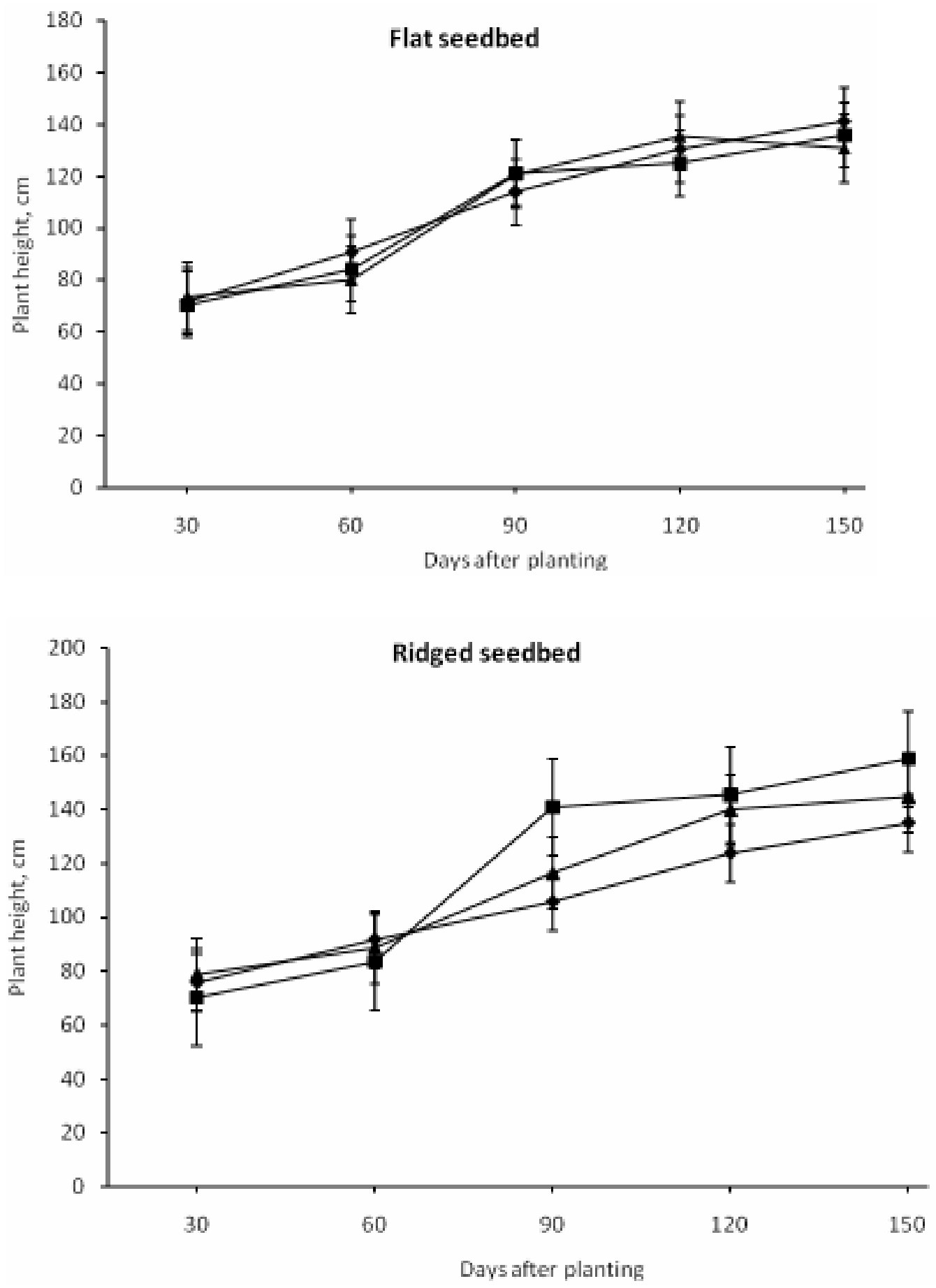

Figure 1. Relationship between plant height and days after planting in taro grown on a flat and ridged seedbed $(\diamond) 0.5 \mathrm{~m}$ $\times 0.5 \mathrm{~m}$ (ם) $0.75 \mathrm{~m} \times 0.75 \mathrm{~m} \quad$ () $1 \mathrm{~m} \times 1 \mathrm{~m}$. 

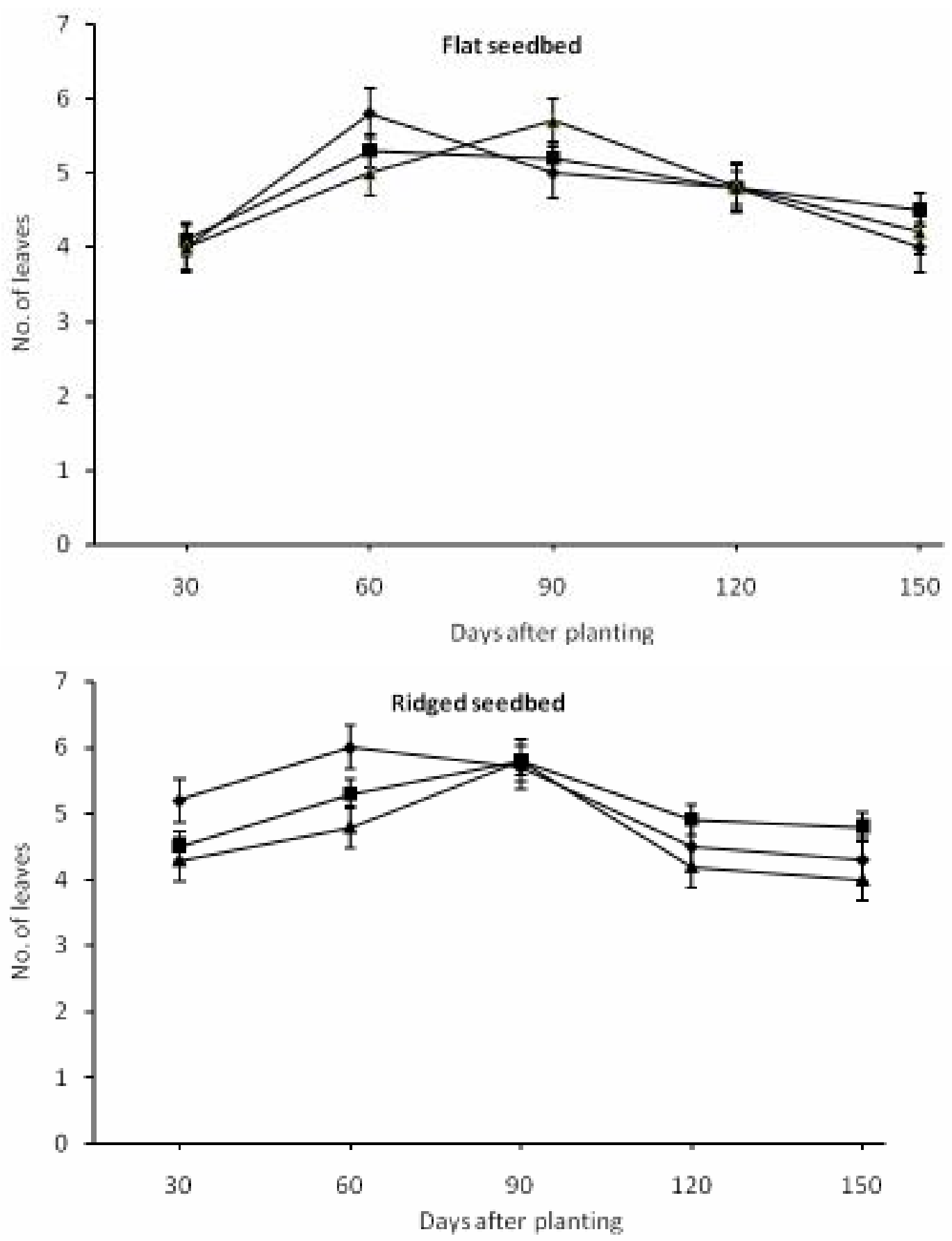

Figure 2. Relationship between number of leaves and days after planting in taro grown on a flat and ridged seedbed $0.5 \mathrm{~m} \times 0.5 \mathrm{~m} \quad(\boldsymbol{\square}) 0.75 \mathrm{~m} \times 0.75 \mathrm{~m} \quad(\boldsymbol{\Delta}) 1 \mathrm{~m} \times 1 \mathrm{~m}$.

average of 5.9 and $6.6 \mathrm{t} \mathrm{ha}^{-1}$, respectively (FAO, 2008). However, using high plant population may not be recommended because of the enormous amount of planting material that would be needed, whereas availability of planting material is an everpresent problem in Taro production (Eze and Okorji, 2003). Besides, there is reduced net return per unit of planting material at high plant 

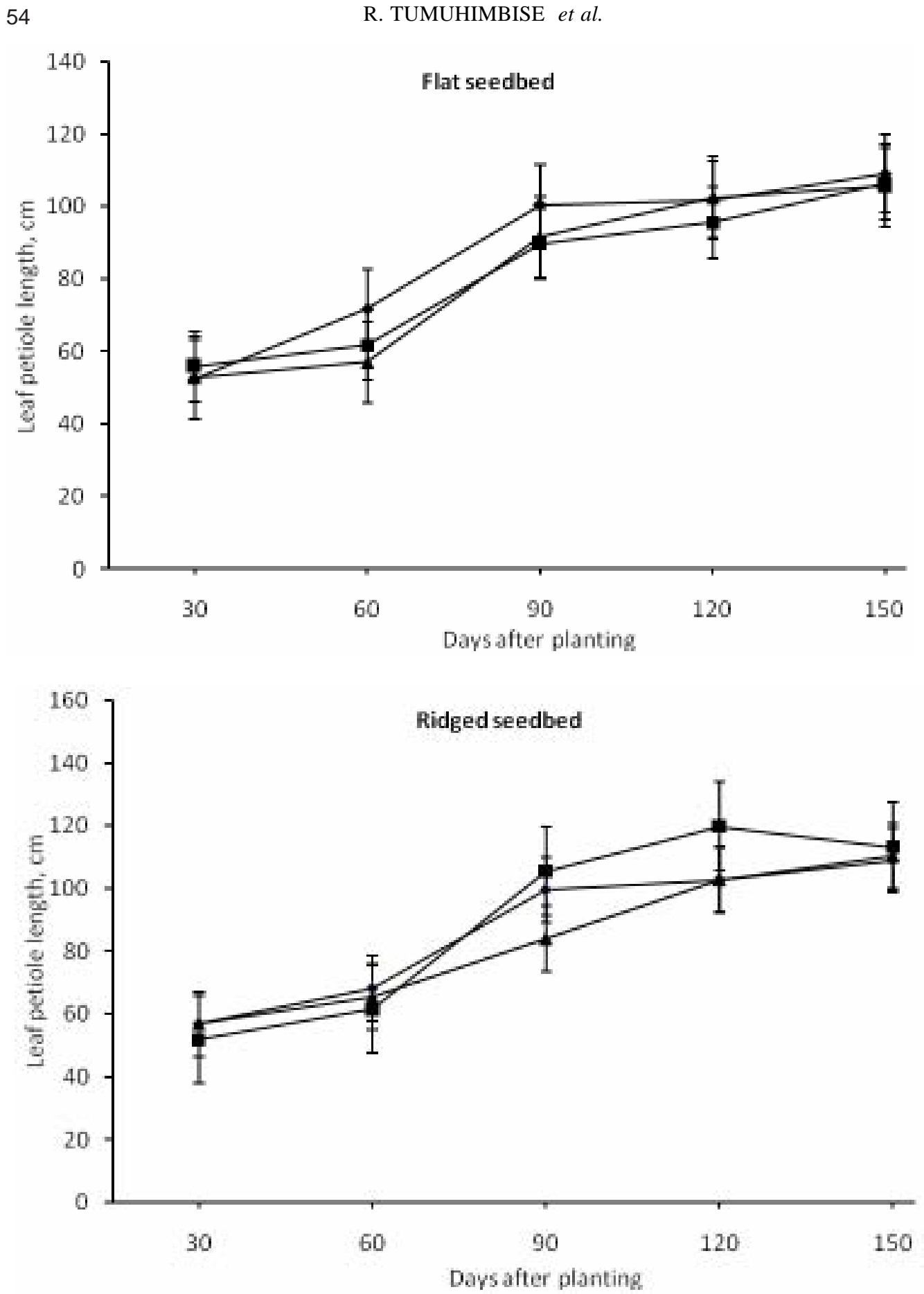

Figure 3. Relationship between leaf petiole length and days after planting in taro grown on a flat and ridged seedbed $\Delta) 0.5 \mathrm{~m}$ $\times 0.5 \mathrm{~m}$ ( $\mathbf{\square}) 0.75 \mathrm{~m} \times 0.75 \mathrm{~m}(\boldsymbol{\Delta}) 1 \mathrm{~m} \times 1 \mathrm{~m}$ 

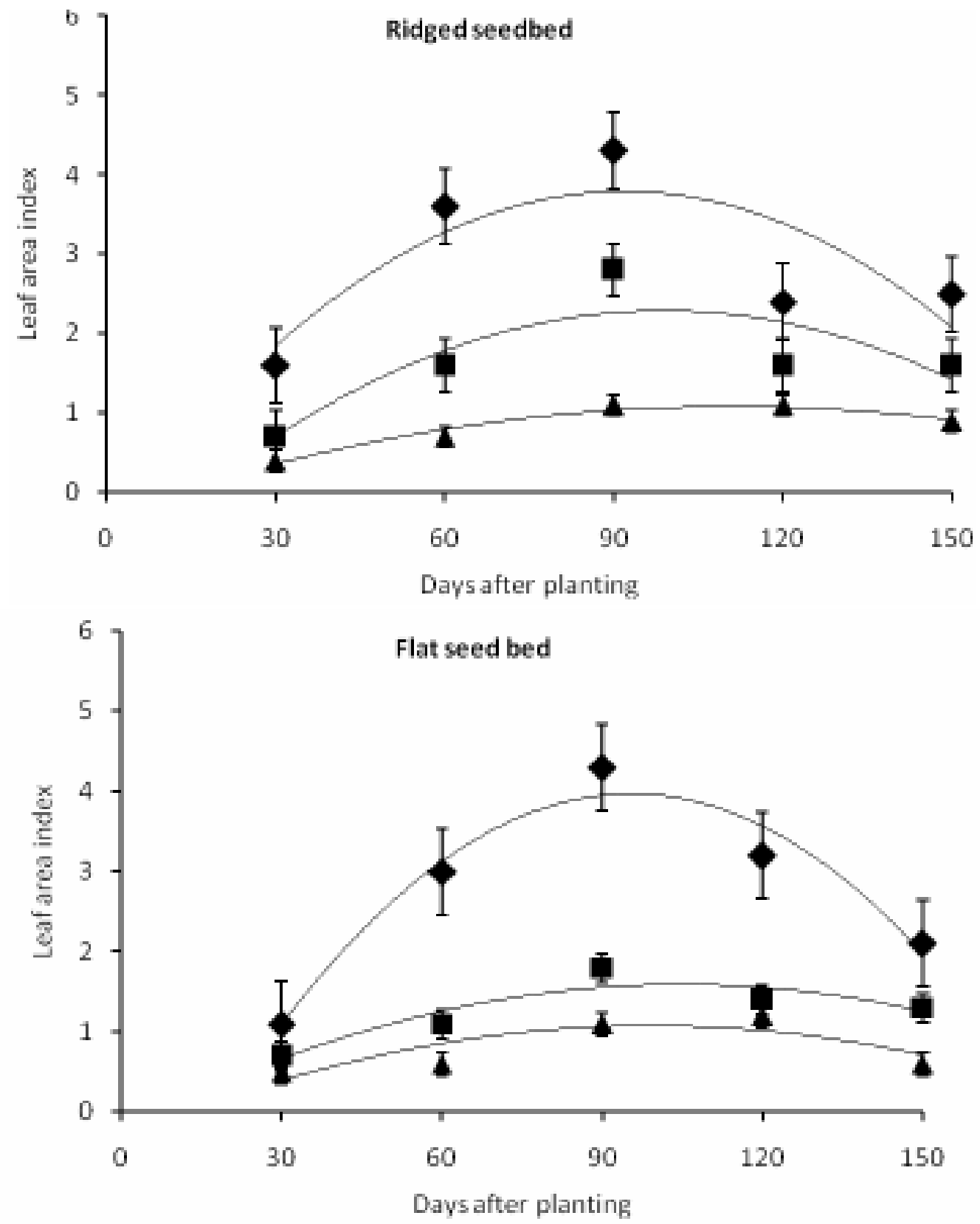

Figure 4. Relationship between leaf area index and days after planting in taro grown on flat and ridged seedbed $0.5 \mathrm{~m}$ $\times 0.5 \mathrm{~m}$ ( $\mathbf{\square}) 0.75 \mathrm{~m} \times 0.75 \mathrm{~m}(\boldsymbol{\Delta}) 1 \mathrm{~m} \times 1 \mathrm{~m}$.

populations (Ajijola, 2003; Echebiri, 2004). From this study, a moderately wide spacing of $0.75 \mathrm{~m} \mathrm{x}$ $0.75 \mathrm{~m}$ which produced an acceptable yield of 5.5 $-6.8 \mathrm{t} \mathrm{ha}^{-1}$ would be recommended.

It was observed that LAI and corm development were not in synchrony (Fig. 4 versus Fig. 7). Maximum LAI was observed 90 DAP and declined thereafter, implying that the critical phase of tuber growth was in a period of declining LAI. It is likely that the yield potential of Taro may not have been realised during this study because the declining LAI would not 

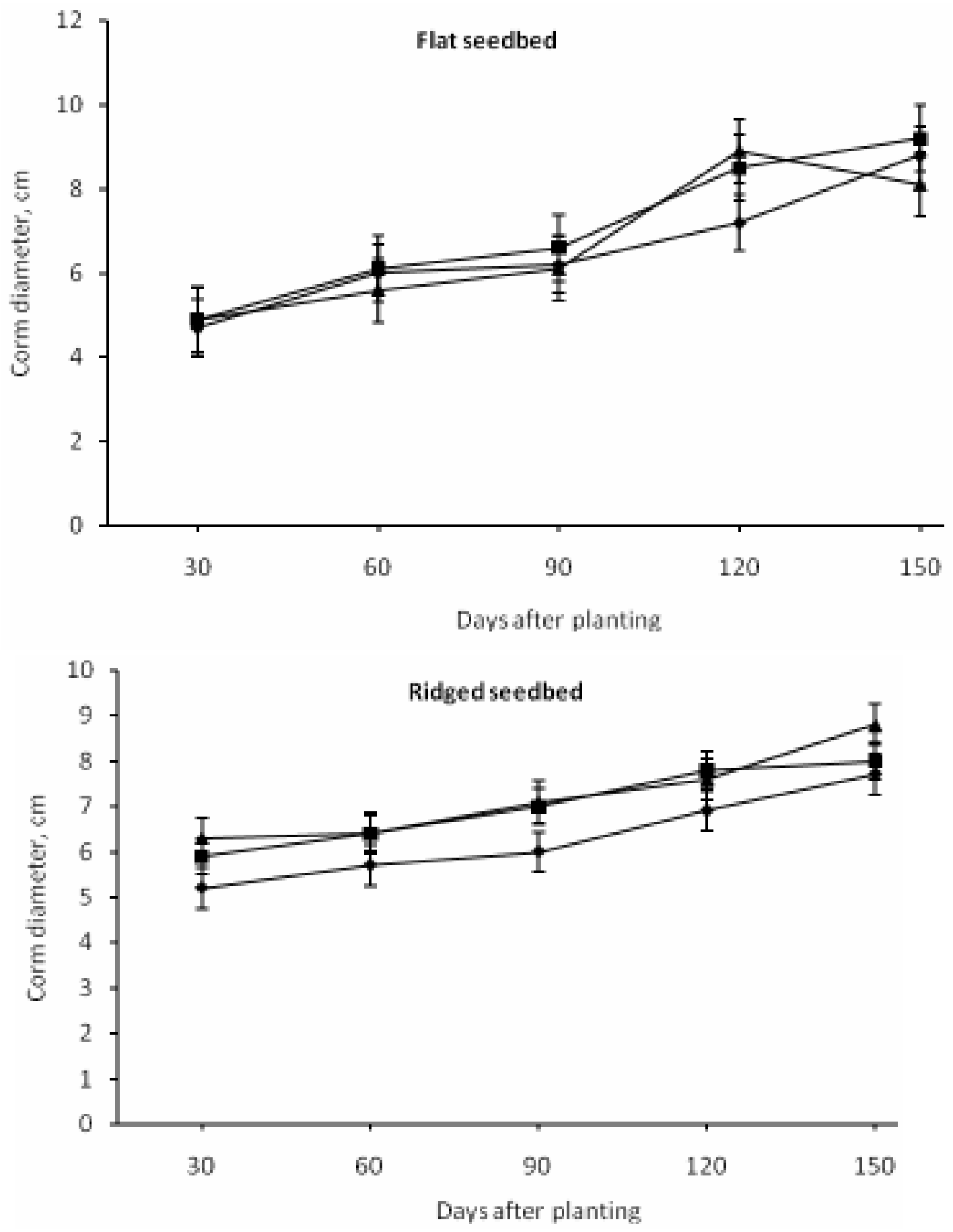

Figure 5. Relationship between corm diameter and days after planting in taro grown on a flat and ridged seedbed $) 0.5 \mathrm{~m}$ x $0.5 \mathrm{~m}$; ( ) $0.75 \mathrm{~m} \times 0.75 \mathrm{~m}$; (A) $1 \mathrm{~m} \times 1 \mathrm{~m}$. 

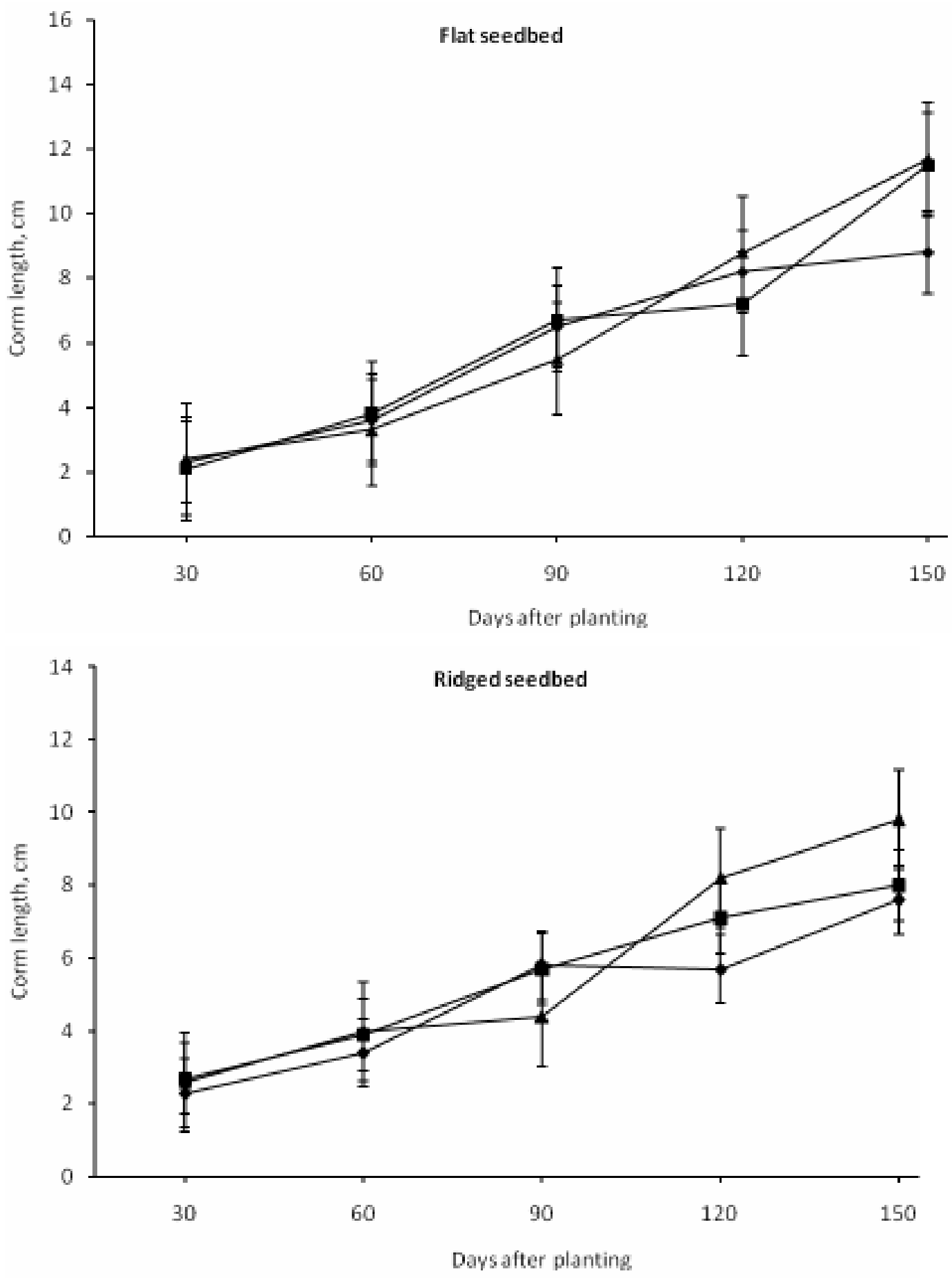

Figure 6 . Relationship between corm length and days after planting in taro grown on a flat and ridged seedbed $(\nabla) 0.5 \mathrm{~m}$

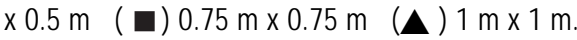



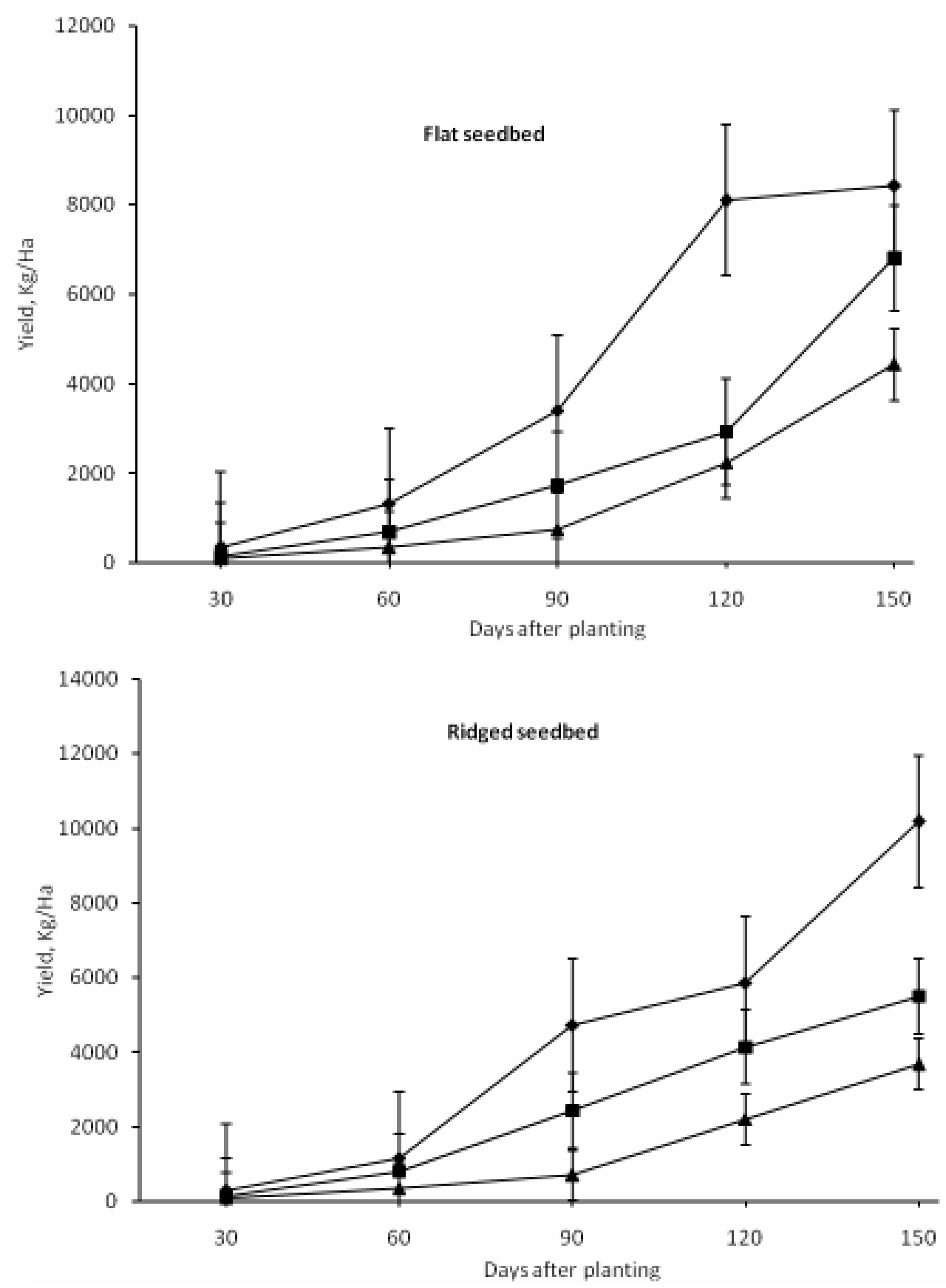

Figure 7. Relationship between corm yield and days after planting in taro grown on a flat and ridged seedbed $0.5 \mathrm{~m}$ $\times 0.5 \mathrm{~m}$ ( $) 0.75 \mathrm{~m} \times 0.75 \mathrm{~m} \quad(\boldsymbol{\Delta}) 1 \mathrm{~m} \times 1 \mathrm{~m}$.

guarantee higher dry matter accumulation. intensive management in association with However, it is noteworthy that the yield obtained commercial production, higher Taro yields can in this study was without additional production be obtained in Uganda. inputs (water, fertilisers, etc). Therefore, with 
Although seedbed type did not significantly affect Taro growth and yield in this study, other studies have on the contrary reported increased yields. For example, Ndon et al. (2003), Anikwe et al. (2007) and Agbede (2008) showed that conventional tillage is disadvantageous to soil fertility and subsequently Taro yield, thereby recommending use of tillage practices that conserve soil and water. From this study, however, it may be recommended that the choice of the seedbed type to be used for Taro production should depend on topography and the amount moisture in the soil. For example, ridges may be used in flooded or wetlands, which are susceptible to extreme floods during heavy rains to provide better aeration for root development. However, the major difficulty with ridge planting in Uganda, which on average receives $>1000 \mathrm{ml}$ rainfall per year, would be the gradual wash down of the ridge tops during the rains thereby decreasing the height of ridges, exposing tubers and thus, affecting corm growth.

\section{ACKNOWLEDGEMENT}

The Swedish International Development Cooperation Agency (SIDA) through the Lake Victoria Research Initiative (VicRes) of the InterUniversity Council of East Africa (IUCEA) funded this study. The information presented does not represent the views of SIDA/VicRes/IUCEA or the respective institutions to which the researchers are affiliated.

\section{REFERENCES}

Agbede, T. M. 2008. Nutrient availability and cocoyam yield under different tillage practices. Soil and Tillage Research 99: $49-$ 57.

Agueguia, C. A. Fatokun and Hahn, S. K. 1992. Protein analysis of ten cocoyam, Xanthosoma sagittifolium (L.). Schott and Colocasis esculenta (L.) Schott genotypes, Root crops for food security in Africa. Proceedings of the fifth triennial symposium, Kampala, Uganda. pp. 348.

Ajijola, S. 2003. Efficiency of resource use among cocoyam farmers in Owo Local Government area of Ondo State, Nigeria. Moor Journal of Agricultural Research 4: 281-287

Echebiri, R. N. 2004. Socio-Economic factors and resource allocation in cocoyam production in Abia State, Nigeria: A case study. Journal of Sustainable Tropical Agricultural Research 9: 69-73

Eze, C. C. and Okorji, E.C. 2003. Cocoyam production by women farmers under improved and local technologies in Imo State, Nigeria. African Journal of Sciences 5(1):113-116

Ezumah, H.C and Plucknett, D.L. 1973. Response of Taro, Colocasia esculenta (L.) Schott, to water management, plot preparation and population, $3^{\text {rd }}$ int.symp.Trop.Root Crops, Ibadan, Nigeria.

Food and Agricultural Organisation (FAO). 2008. FAOSTATbase. http://www.fao.org (Accessed 20 January 2009).

Goenaga, R. 1996. Taro yield and dry matter distribution under upland conditions in Puerto Rico. African Crop Science Journal 4: 289-294

Goenaga, R. and Chardón, U. 1995. Growth, yield and nutrient uptake of Taro grown under upland conditions. Journal of Plant Nutrition 18: 1037-1048.

Goenaga, R. and Singh, U. 1996. Estimation of leaf area of Taro [Colocasia esculenta (L.) Schott] from linear measurements. Journal of Agriculture of University of Puerto Rico 80: 183-185.

Howeler, R. H., Ezumah, H. C. and Midmore, D. J. 1993. Tillage systems for root and tuber crops in the tropics. Soil and Tillage Research 27: $211-240$.

IPGRI (International Plant Genetic Resources Institute). 1999. Descriptors for Taro (Colocasia esculenta). IPGRI, Rome, Italy.

Ki-zerbo, J. 1990. African pre-history. Pages 313 - 319 in: General history of Africa. James Currey Ltd. London, UK.

Ndon, B. A., Ndulaka, N. H. and Ndaeyo, N. U. 2003. Stabilisation of yield parameters and some nutrient components in cocoyam cultivars with time in Uyo, southern Nigeria. Global Journal of Agricultural Sciences 2: $74-78$. 
Onwueme, I.C. 1994. Tropical root and tuber crops - Production, perspectives and future prospects. FAO Plant Production \& Protection Paper 126, FAO, Rome, Italy. pp. 228.

Onwueme, I.C. 1999. Taro cultivation in Asia and the Pacific. RAP Publication: 1999/16. Food and Agriculture Organization of the United Nations Regional Office for Asia and the Pacific. Bangkok, Thailand.

Prasad, H.K. and Singh, U. 1992 Effect of photoperiod and temperature on growth and development of Taro (Colocasia esculenta (L.) Schott). In: Singh, U. (Ed.), pp. 29-35. Proceedings of Workshop on Taro and Tanier Modeling, Honolulu, HI. 8-14 Aug. 1991. Res. Ext. Ser. 136. College of Trop. Agric. and Human Resour., Univ. of Hawaii, Honolulu.
Scholberg, J., McNeal, B. L., Jones, J. W., Boote, K. J., Stanley, C. D. and Obreza, T. A. 2000. Growth and Canopy Characteristics of FieldGrown Tomato. Agronomy Journal 92:152159

Talwana, H. A. L., Serem, A.K., Ndabikunze, B.K., Nandi, J.O.M., Tumuhimbise, R., Kaweesi, T., Chumo, E.C. and Palapala, V. 2009. Production status and prospects of Cocoyam (Colocasia esculentum Schott.) for improving food and income security in East Africa. Journal of Root Crops 35: 98-107.

Valerio, C. E. 1988. Notes on the phenology and pollination of Xanthosoma wendlandii (Araceae) in Costa Rica. Revista de Biologýa Tropical 36: 55-61

Wang, J. 1983 (Ed). Taro - a review of Colocasia esculenta and its potentials. University of Hawaii Press, Honolulu. 